\title{
OBSERVATIONS ON THE CONCENTRATING AND DILUTING MECHANISMS OF THE DISEASED KIDNEY *
}

\author{
By NEAL S. BRICKER, RICHARD R. DEWEY, † HERBERT LUBOWITZ, \\ JAMES STOKES AND TOVE KIRKENSGAARD \\ (From the Departments of Medicine [Renal Division], Preventive Medicine and Surgery, \\ Washington University Medical School, St. Louis, Mo.)
}

(Submitted for publication October 6, 1958; accepted November 25, 1958)

The concentrating and diluting mechanisms of the normal kidney contribute in an impressive manner to the defense of water economy. In health, a given amount of solute may be excreted in a widely varying volume of water which is determined under most circumstances by the water needs of the organism. This ability to regulate the osmolality of the urine accounts for a range of urine concentrations which extends from marked hypotonicity to marked hypertonicity. ${ }^{1}$ In the course of advancing renal disease, the total amount of solute excretion per 24 hours may remain comparable to values achieved in health. It is a clinical observation of long standing, however, that the patient's ability to vary the volume of water in which this solute is contained becomes progressively limited. Hence, the range over which urine tonicity may be extended becomes more and more restricted. Typically, this restriction is manifested initially by a decrease in the maximum attainable urine osmolality, followed somewhat later by a progressive inability to decrease the tonicity of the urine. Ultimately, urine tonicity deviates little in either direction from the concurrent plasma osmolality, and the stage of so-called "permanent isosthenuria" or "fixed specific gravity" supervenes.

The intrarenal mechanisms responsible for the impaired ability to concentrate and dilute the urine in chronic renal disease have never been adequately explained. Although the opinion is widely held that the specific tubular sites for the

* Supported by grants from the National Institutes of Health, United States Public Health Service, and the Department of the Army, Research and Development Branch (DA-49-007-MD-772).

$\dagger$ Fellow of the American Heart Association.

1 A discussion of current concepts of the concentrating and diluting mechanisms of the normal kidney may be found in a recent paper by Berliner, Levinsky, Davidson and Eden (1). concentrating and diluting operations are destroyed by the underlying pathologic processes, no experimental confirmation of this thesis has yet appeared. On the contrary, certain theoretic considerations render this explanation open to serious question. Thus, within the context of the conventional theory, the loss of concentrating ability before that of diluting ability must be related to pathologic involvement of the site (or sites) of concentration in the tubule prior to the site of dilution. Moreover, this sequence of events must be identical in all chronic renal diseases associated with the classic pattern of functional alterations, irrespective of the etiology or pathologic characteristics of the specific disease entity. The supposition that such an orderly and predictable progression of anatomic alterations may occur in a heterogeneous group of renal diseases is difficult to reconcile with recorded histologic data. Within recent years several groups have favored an alternative explanation (2-5). This would attribute the impaired ability to concentrate and dilute the urine in chronic Bright's disease to functional adaptations in the persisting nephrons of the diseased kidney. ${ }^{2}$ Refractory isosthenuria could, therefore, evolve in the face of normal concentrating and diluting mechanisms in the surviving nephrons.

Evidence has recently been presented from this laboratory which indicates that the persisting nephrons in the chronically diseased kidney retain many normal functional characteristics (6). The present studies represent an attempt to investigate the functional integrity of the concen-

2 The two adaptations which have been considered are: 1$)$ a continuing osmotic diuresis due to high filtered loads of urea; and/or 2) an increased glomerular filtration rate per functioning nephron. Either of these could account for high rates of urine flow past the concentrating and diluting sites. 
trating and diluting mechanism in the diseased kidney. An experimental model has been constructed which allows for the study of a diseased kidney in an essentially normal internal environment. Three different forms of renal disease have been induced experimentally in dogs. In each animal, the lesion has been produced in only one kidney and the opposite organ has been maintained intact. The control kidney serves as a standard of comparison for the diseased organ. Moreover, the normal kidney prevents significant abnormalities from occurring in body fluids, regardless of the severity of the contralateral renal lesion. If the development of impaired concentrating and diluting ability in a diseased kidney results from disruption of tubular transport systems, refractory isosthenuria should ultimately occur regardless of either the functional capacity of the opposite kidney, or the environment in which the diseased organ resides. Conversely, if the progressive inability to modify the tonicity of the urine depends upon adaptive changes (i.e., continuing osmotic diuresis) in functionally intact nephrons, the diseased kidney should retain essentially normal concentrating and diluting characteristics in an environment which minimizes any such adaptations invoked by the uremic state.

\section{METHODS}

Sixty experiments were performed on 17 female mongrel dogs. In each animal one of three types of renal disease was induced in a single kidney and the opposite organ was maintained intact. The forms of unilateral renal disease include the following: 1) A chronic disease which is characterized by marked contraction of the involved kidney and histologic abnormalities of the persisting nephrons including dilatation and atrophy of tubules, intratubular casts, interstitial fibrosis, decrease in size of some glomerular tufts and thickening of glomerular basement membranes. This lesion which has been previously described in detail (7) is produced by perfusing the totally anoxic kidney with a solution of an aminonucleoside (6-dimethyl aminopurine 3-amino-D ribose) and diverting the renal venous return to prevent recirculation. 2) Unilateral pyelonephritis produced by exposing one kidney through a flank incision, massaging it manually for five minutes, puncturing the renal parenchyma approximately 150 times with a 22 gauge needle and injecting $1 \mathrm{ml}$. of a four hour culture of $E$. coli intravenously. Following the injection of bacteria the ureter is clamped for 20 minutes (8). Histologically, the diseased kidneys demonstrate changes of both acute and chronic pyelonephritis. 3) A reversible renal le- sion induced by rendering the experimental kidney anoxic for 30 minutes and then perfusing it with a saline solution under moderate pressure. The histologic changes are limited to the tubules and include vacuolated epithelial cells and intratubular casts (7).

The concentrating capacity of the diseased kidney was studied, employing three different protocols. The maximum urine/plasma osmolal ratio was determined following water withdrawal for at least 14 hours. The maximum value for solute-free water abstracted $\left(\mathrm{T}_{\mathrm{H}_{20} \mathrm{O}}^{\mathrm{e}}\right)$ was measured during osmotic diuresis induced by mannitol and with constant vasopressin infusion. Values for $\mathrm{T}^{\mathbf{6}}{ }_{\mathrm{H}_{2} \mathrm{O}}$ were also recorded during the infusion of hypertonic saline. The diluting capacity of the diseased kidney was investigated following the intragastric administration of from 40 to $70 \mathrm{ml}$. per $\mathrm{Kg}$. of water containing $5 \mathrm{ml}$. of absolute alcohol. Additional alcohol was infused in 0.45 per cent saline during the course of each experiment. The diluting capacity was also studied during isotonic expansion of extracellular fluid volume. In a number of experiments, a moderate amount of water ( 20 to $30 \mathrm{ml}$. per $\mathrm{Kg}$.) was administered without alcohol in order to study intermediate ranges of water diuresis.

In each animal a preliminary bladder-splitting procedure was performed in order to construct two permanent hemi-bladders. Each of the latter drains one kidney and allows for evaluation of the separate functions of the individual kidneys. Clearance studies were performed with the animals in the standing position and unanesthetized state. Creatinine and PAH were routinely included in the sustaining infusions. Details of the clearance techniques and analytic procedures have been described in previous communications $(7,9)$. In all experiments, the behavior of the diseased kidney was contrasted with the simultaneous pattern of the contralateral intact organ.

\section{RESULTS}

\section{Concentrating capacity}

During osmotic diuresis and with maximum vasopressin activity, the concentrating mechanism of the normal kidney in the dog abstracts from 5 to $8 \mathrm{ml}$. of water per $100 \mathrm{ml}$. of glomerular filtrate. This volume of water reabsorbed in excess of an isosmotic equivalent of solute is referred to as $\mathrm{T}^{\mathrm{c}}{ }_{\mathrm{H}_{2} \mathrm{O}}$. Measurement of $\mathrm{T}^{\mathrm{c}} \mathrm{H}_{2} \mathrm{O}$ has been made in 20 experiments on 11 dogs (six with an aminonucleoside-induced lesion and five with pyelonephritis) during mannitol and Pitres$\sin ^{\circledR}$ (vasopressin) infusion. Two representative experiments, one on an animal with an aminonucleoside-induced lesion and the other with pyelonephritis, are shown in Table I. Glomerular filtration rates of the experimental (diseased) kid- 
TABLE I

Concentrating capacity of the diseased and intact kidneys during the infusion of mannitol and vasopressin in two animals with unilateral renal disease*

\begin{tabular}{|c|c|c|c|c|c|c|c|c|c|c|c|}
\hline \multirow{2}{*}{$\begin{array}{c}\text { Clearance } \\
\text { period }\end{array}$} & \multicolumn{2}{|c|}{ GFR } & \multicolumn{2}{|c|}{ V } & \multicolumn{2}{|c|}{ Cosm } & \multirow[b]{2}{*}{ Posm } & \multicolumn{2}{|c|}{$\mathrm{T}^{\circ} \mathrm{H}_{2} \mathrm{O}$} & \multicolumn{2}{|c|}{$\underset{\times 100}{T^{\circ}{ }_{20} / G F R}$} \\
\hline & Exp. & Cont. & Exp. & Cont. & Exp. & Cont. & & Exp. & Cont. & Exp. & Cont. \\
\hline A. Dog Pr. & \multicolumn{2}{|c|}{$\begin{array}{c}\text { ml. } / \min . \\
(14.8 \mathrm{Kg} .)\end{array}$} & Aminonucle & $\begin{array}{c}\text { ml./min. } \\
\text { nucleoside }\end{array}$ & \multicolumn{2}{|c|}{$\begin{array}{l}\text { ml./min. } \\
\text { esion (185 }\end{array}$} & $\begin{array}{l}\text { Osm./L. } \\
\text { induction) }\end{array}$ & \multicolumn{2}{|c|}{ ml./min. } & & \\
\hline $\begin{array}{l}1 \\
2 \\
3 \\
4 \\
5\end{array}$ & $\begin{array}{l}11.2 \\
11.2 \\
11.5 \\
12.1 \\
12.1\end{array}$ & $\begin{array}{l}39.4 \\
43.6 \\
40.9 \\
43.0 \\
43.0\end{array}$ & $\begin{array}{l}2.0 \\
2.4 \\
2.5 \\
2.7 \\
2.7\end{array}$ & $\begin{array}{l}4.7 \\
6.2 \\
5.9 \\
6.8 \\
6.6\end{array}$ & $\begin{array}{l}2.62 \\
3.15 \\
3.29 \\
3.53 \\
3.49\end{array}$ & $\begin{array}{c}7.14 \\
9.0 \\
8.77 \\
10.10 \\
9.88\end{array}$ & $\begin{array}{l}301 \\
302 \\
303 \\
306 \\
309\end{array}$ & $\begin{array}{l}0.66 \\
0.76 \\
0.77 \\
0.84 \\
0.81\end{array}$ & $\begin{array}{l}2.49 \\
2.85 \\
2.85 \\
3.30 \\
3.27\end{array}$ & $\begin{array}{l}5.9 \\
6.8 \\
6.7 \\
6.9 \\
6.7\end{array}$ & $\begin{array}{l}6.3 \\
6.5 \\
7.0 \\
7.8 \\
7.6\end{array}$ \\
\hline
\end{tabular}

B. Dog Te. (7.5 Kg.) Pyelonephritis (29 days after induction)

$\begin{array}{llllllllllll}1 & 14.7 & 23.5 & 4.7 & 5.4 & 4.84 & 6.03 & 322 & 0.19 & 0.68 & 1.3 & 2.9 \\ 2 & 15.1 & 23.5 & 4.7 & 5.9 & 5.0 & 6.56 & 333 & 0.28 & 0.66 & 1.8 & 2.8 \\ 3 & 15.6 & 23.7 & 4.5 & 5.9 & 5.02 & 6.83 & 335 & 0.52 & 0.98 & 3.3 & 4.1 \\ 4 & 13.6 & 23.3 & 3.9 & 5.4 & 4.57 & 6.71 & 337 & 0.67 & 1.33 & 4.9 & 5.7 \\ \mathbf{5} & 14.1 & 23.0 & 3.8 & \mathbf{5 . 3} & 4.55 & \mathbf{6 . 7 2} & 346 & \mathbf{0 . 7 3} & \mathbf{1 . 4 7} & \mathbf{5 . 2} & \mathbf{6 . 4}\end{array}$

* Exp. refers to experimental (diseased) kidney; Cont. refers to control (intact) kidney; V, urine flow ; Cosm, osmolal clearance; $\mathrm{T}^{\circ} \mathrm{H}_{2} \mathrm{O}$, solute-free water abstracted in the concentration process; Posm, plasma osmolality.

neys were significantly decreased both as compared with the original level of function before induction of disease and with the concurrent value of the control (intact) kidney. Values for $\mathrm{T}^{\mathrm{c}}{ }_{\mathrm{H}_{2} \mathrm{O}}$ for the experimental kidneys were also appreciably below those for the control kidneys. However, in both dogs, the ratios of solute-free water abstracted per $100 \mathrm{ml}$. of glomerular filtrate $\left(\mathrm{T}^{\mathrm{c}} \mathrm{H}_{2} \mathrm{O} /\right.$ GFR $\times 100$ ) were well within the normal range. Moreover, $\mathrm{T}_{\mathbf{H}_{2} \mathrm{O}} / \mathrm{GFR}$ for the experimental kidney closely approximated the values for the intact organ. The slight superiority of values for the intact kidneys has been noted in 17 of the 20 experiments and will be referred to again.

In Table II, the concentrating capacity of the diseased organ in an animal with an aminonucleoside-induced lesion is shown during the administration of $\mathbf{5}$ per cent sodium chloride. The pat- tern is identical to that seen during the mannitol and vasopressin experiments. Thus, although GFR in the diseased kidney was decreased by over 60 per cent, the values for $\mathrm{T}^{\mathrm{c}}{ }_{\mathrm{H}_{2} \mathrm{O}} \mathrm{O} / \mathrm{GFR}$ were within the normal range, and closely approximated those for the intact organ.

The maximum urine/plasma osmolal ratios for the diseased and intact kidneys are shown in Table III for several representative dogs. In all animals, the experimental organ has retained the ability to elaborate a hypertonic urine, although the values have typically been somewhat less than those for the control organs.

\section{Diluting capacity}

Representative experiments for two dogs subjected to water-loading and alcohol administration

TABLE II

Concentrating capacity of the diseased and intact kidneys during the infusion of 5 per cent NaCl at 5 ml. per minute in a dog with unilateral aminonucleoside-induced renal disease *

\begin{tabular}{|c|c|c|c|c|c|c|c|c|c|c|c|}
\hline \multirow{2}{*}{$\begin{array}{l}\text { Clearance } \\
\text { period }\end{array}$} & \multicolumn{2}{|c|}{ GFR } & \multicolumn{2}{|c|}{ V } & \multicolumn{2}{|c|}{ Cosm } & \multirow[b]{2}{*}{ Posm } & \multicolumn{2}{|c|}{$\mathrm{T}^{\circ} \mathrm{H}_{2} \mathrm{O}$} & \multicolumn{2}{|c|}{$\underset{\times 100}{\mathrm{~T}^{\mathrm{o}} \mathrm{H}_{2} \mathrm{O} / \mathrm{GFR}}$} \\
\hline & Exp. & Cont. & Exp. & Cont. & Exp. & Cont. & & Exp. & Cont. & Exp. & Cont. \\
\hline & \multicolumn{2}{|c|}{$m l . / m i n$} & \multicolumn{2}{|c|}{ ml./min. } & \multicolumn{2}{|c|}{ ml./min. } & mOsm./L. & \multicolumn{2}{|c|}{ ml./min. } & & \\
\hline $\begin{array}{l}1 \\
2 \\
3 \\
4 \\
5\end{array}$ & $\begin{array}{l}16.0 \\
17.9 \\
17.1 \\
15.7 \\
17.1\end{array}$ & $\begin{array}{l}46.5 \\
45.6 \\
48.8 \\
43.3 \\
44.3\end{array}$ & $\begin{array}{l}1.17 \\
1.30 \\
1.40 \\
1.45 \\
1.56\end{array}$ & $\begin{array}{l}2.61 \\
2.69 \\
3.03 \\
2.93 \\
3.27\end{array}$ & $\begin{array}{l}1.92 \\
2.14 \\
2.24 \\
2.27 \\
2.38\end{array}$ & $\begin{array}{l}5.01 \\
5.17 \\
5.73 \\
5.41 \\
5.86\end{array}$ & $\begin{array}{l}336 \\
347 \\
353 \\
362 \\
373\end{array}$ & $\begin{array}{l}0.75 \\
0.84 \\
0.84 \\
0.82 \\
0.82\end{array}$ & $\begin{array}{l}2.40 \\
2.48 \\
2.70 \\
2.48 \\
2.59\end{array}$ & $\begin{array}{l}4.7 \\
4.7 \\
4.9 \\
5.2 \\
4.8\end{array}$ & $\begin{array}{l}5.2 \\
5.4 \\
5.5 \\
5.7 \\
5.9\end{array}$ \\
\hline
\end{tabular}

* Dog He. $(10.1 \mathrm{Kg}$.$) . The experiment was performed 51$ days after induction of the lesion. 
TABLE III

Maximum osmolal urine/plasma ratios of diseased and intact kidneys

\begin{tabular}{|c|c|c|c|c|c|c|c|c|c|}
\hline \multirow[b]{2}{*}{ Dog } & \multirow[b]{2}{*}{ Wt. } & \multirow[b]{2}{*}{ Day* } & \multicolumn{2}{|c|}{ GFR } & \multirow[b]{2}{*}{ Posm† } & \multicolumn{2}{|c|}{ Uosmt } & \multicolumn{2}{|c|}{$\underset{\text { ratiof }}{\operatorname{Max} . U / P}$} \\
\hline & & & Exp. & Cont. & & Exp. & Cont. & Exp. & Cont. \\
\hline & $K g$ & & \multicolumn{2}{|c|}{ ml./min. } & mOsm./L. & \multicolumn{2}{|c|}{ mOsm./L. } & & \\
\hline He.t & 10.2 & 35 & 11.7 & 33.3 & 293 & 675 & 1,250 & 2.30 & 4.27 \\
\hline Pr.t & 15.2 & 49 & 11.9 & 41.2 & 289 & 1,139 & 1,413 & 3.94 & 4.89 \\
\hline Sp. $\$$ & 9.5 & 17 & 16.7 & 22.3 & 297 & 945 & 1,092 & 3.18 & 3.68 \\
\hline Te. $\$$ & 7.5 & 29 & 14.7 & 23.5 & 300 & 1,097 & 1,391 & 3.66 & 4.64 \\
\hline Fu. $\S$ & 12.7 & 35 & 18.3 & 28.5 & 294 & 881 & 1,002 & 3.0 & 3.41 \\
\hline
\end{tabular}

* Day refers to the time elapsed after induction of the lesion.

$\dagger$ Posm, plasma osmolality; Uosm, urine osmolality; Max. U/P ratio, maximum urine/plasma osmolal ratio. Aminonucleoside-induced disease.

$\$$ Pyelonephritis.

are shown in Table IV. One dog (IV-A) had an aminonucleoside-induced lesion; the other (IV-B) had chronic pyelonephritis. Expression of data is similar to that employed in the concentration studies except that free-water clearance $\left(\mathrm{C}_{\mathrm{H}_{2} \mathrm{O}}\right)$ rather than $\mathrm{T}^{\mathrm{c}}{ }_{\mathrm{H}_{2} \mathrm{O}}$ has been measured. The term $\mathrm{C}_{\mathrm{H}_{2} \mathrm{O}} / \mathrm{GFR} \times 100$ indicates the number of $\mathrm{ml}$. of free-water in the urine per $100 \mathrm{ml}$. of glomerular filtrate. Despite marked reduction in GFR, values for $\mathrm{C}_{\mathrm{H}_{2} \mathrm{O}} / \mathrm{GFR}$ were within the normal range for the diseased kidneys. Of some interest, however, is the unexpected and quite consistent finding that $\mathrm{C}_{\mathrm{H}_{2} \mathrm{O}}$ /GFR was greater for the diseased organs than for the intact kidneys.

The diluting capacity of the diseased kidney was also studied during isotonic expansion of extracellular fluid volume. The results of such an experiment performed on an animal with an aminonucleoside-induced lesion are shown in Table V. Although GFR for the experimental kidney was less than $5 \mathrm{ml}$. per minute $\mathrm{C}_{\mathrm{H}_{2} \mathrm{O}} / \mathrm{GFR}$ increased progressively and, as was noted during water-loading and alcohol administration, the values for this ratio exceeded those for the intact organ.

Twenty-five experiments have been performed on $10 \mathrm{dogs}$ following the administration of a moderate dose of water (i.e., 20 to $30 \mathrm{ml}$. per $\mathrm{Kg}$.) without alcohol. These studies permit the comparison of the diseased and intact kidneys during the ascending limb of a sub-maximal water diuresis. The results of experiments on four dogs are shown in Table VI. Two animals had a reversible lesion induced by saline perfusion of the anoxic kidney; one had an aminonucleoside-induced lesion and one had pyelonephritis. In the

TABLE IV

Diluting capacity of the diseased and intact kidneys following water-loading and alcohol administration

\begin{tabular}{|c|c|c|c|c|c|c|c|c|c|c|c|}
\hline \multirow{2}{*}{$\begin{array}{l}\text { Clearance } \\
\text { period }\end{array}$} & \multicolumn{2}{|c|}{ GFR } & \multicolumn{2}{|c|}{$\mathrm{v}$} & \multicolumn{2}{|c|}{ Cosm } & \multirow[b]{2}{*}{ Posm } & \multicolumn{2}{|c|}{$\mathrm{C}_{\mathrm{H}_{2} \mathrm{O}^{*}}$} & \multicolumn{2}{|c|}{$\begin{array}{c}\mathrm{C}_{\mathrm{H}_{2} \mathrm{O} / \mathrm{GFR}} \\
\times 100\end{array}$} \\
\hline & Exp. & Cont. & Exp. & Cont. & Exp. & Cont. & & Exp. & Cont. & Exp. & Cont. \\
\hline A. Dog $\operatorname{Pr}$ & \multicolumn{2}{|c|}{$\begin{array}{l}\text { ml. } / \min . \\
(15.2 \mathrm{Kg} .)\end{array}$} & \multicolumn{2}{|c|}{$\begin{array}{c}m l . / m i n \\
\text { Aminonucleoside-in }\end{array}$} & \multicolumn{3}{|c|}{$\begin{array}{l}\text { ml./min. } m O s m . / L . \\
\text { esion ( } 52 \text { days after induction) }\end{array}$} & \multicolumn{2}{|c|}{ ml./min. } & & \\
\hline $\begin{array}{l}1 \\
2 \\
3 \\
4 \\
5 \\
6\end{array}$ & $\begin{array}{l}13.9 \\
14.2 \\
13.2 \\
14.9 \\
12.6 \\
11.9\end{array}$ & $\begin{array}{l}47.8 \\
48.5 \\
45.8 \\
46.4 \\
44.7 \\
40.6\end{array}$ & $\begin{array}{l}1.84 \\
1.99 \\
2.14 \\
2.25 \\
1.82 \\
1.67\end{array}$ & $\begin{array}{l}4.78 \\
4.90 \\
5.20 \\
5.31 \\
4.60 \\
4.26\end{array}$ & $\begin{array}{l}0.62 \\
0.68 \\
0.69 \\
0.70 \\
0.53 \\
0.47\end{array}$ & $\begin{array}{l}1.53 \\
1.52 \\
1.51 \\
1.57 \\
1.35 \\
1.32\end{array}$ & $\begin{array}{l}296 \\
287 \\
300 \\
305 \\
306 \\
309\end{array}$ & $\begin{array}{l}1.22 \\
1.31 \\
1.45 \\
1.55 \\
1.29 \\
1.20\end{array}$ & $\begin{array}{l}3.25 \\
3.38 \\
3.69 \\
3.74 \\
3.25 \\
2.94\end{array}$ & $\begin{array}{r}8.8 \\
9.2 \\
11.0 \\
10.4 \\
10.2 \\
10.1\end{array}$ & $\begin{array}{l}6.8 \\
7.0 \\
8.1 \\
8.1 \\
7.3 \\
7.2\end{array}$ \\
\hline \multicolumn{3}{|c|}{ B. Dog Ho. $(12.3 \mathrm{Kg})}$. & \multicolumn{5}{|c|}{ Pyelonephritis ( 57 days after induction) } & & & & \\
\hline $\begin{array}{l}1 \\
2 \\
3\end{array}$ & $\begin{array}{l}21.8 \\
22.6 \\
19.5\end{array}$ & $\begin{array}{l}40.7 \\
36.7 \\
36.8\end{array}$ & $\begin{array}{r}2.85 \\
3.15 \\
2.37\end{array}$ & $\begin{array}{l}2.85 \\
4.01 \\
3.85\end{array}$ & $\begin{array}{l}1.04 \\
0.87 \\
0.57\end{array}$ & $\begin{array}{l}1.26 \\
1.20 \\
1.06\end{array}$ & $\begin{array}{l}273 \\
274 \\
276\end{array}$ & $\begin{array}{l}1.81 \\
2.28 \\
1.80\end{array}$ & $\begin{array}{l}1.59 \\
2.81 \\
2.79\end{array}$ & $\begin{array}{r}8.3 \\
10.1 \\
9.2\end{array}$ & $\begin{array}{l}3.9 \\
7.7 \\
7.6\end{array}$ \\
\hline
\end{tabular}

${ }^{*} \mathrm{C}_{\mathrm{H}_{2} \mathrm{O}}$, free-water clearance. 
TABLE V

Effects of sustained isotonic expansion of extracellular fluid $(E C F)$ volume on diluting capacity. of the diseased and intact kidneys*

\begin{tabular}{|c|c|c|c|c|c|c|c|c|c|c|c|}
\hline \multirow{2}{*}{$\begin{array}{c}\text { Clearance } \\
\text { period }\end{array}$} & \multicolumn{2}{|c|}{ GFR } & \multicolumn{2}{|c|}{ v } & \multicolumn{2}{|c|}{ Cosm } & \multirow[b]{2}{*}{ Posm } & \multicolumn{2}{|c|}{$\mathrm{C}_{\mathrm{H} 2 \mathrm{O}}$} & \multicolumn{2}{|c|}{$\begin{array}{c}\mathrm{C}_{\mathrm{H} \geq 0 / \mathrm{O} / \mathrm{GR}} \\
\times 100\end{array}$} \\
\hline & Exp. & Cont. & Exp. & Cont. & Exp. & Cont. & & Exp. & Cont. & Exp. & Cont. \\
\hline & \multicolumn{2}{|c|}{ ml./min. } & \multicolumn{2}{|c|}{ ml./min. } & \multicolumn{2}{|c|}{ ml./min. } & mOsm./L. & \multicolumn{2}{|c|}{ ml./min. } & & \\
\hline $\begin{array}{l}1 \\
2 \\
3 \\
4 \\
5\end{array}$ & $\begin{array}{l}3.7 \\
4.0 \\
3.8 \\
4.9 \\
5.0\end{array}$ & $\begin{array}{l}21.6 \\
22.0 \\
22.5 \\
26.4 \\
24.1\end{array}$ & $\begin{array}{l}0.21 \\
0.42 \\
0.64 \\
0.67 \\
0.76\end{array}$ & $\begin{array}{l}1.15 \\
2.22 \\
2.43 \\
2.86 \\
2.56\end{array}$ & $\begin{array}{l}0.08 \\
0.25 \\
0.31 \\
0.24 \\
0.32\end{array}$ & $\begin{array}{l}0.44 \\
0.53 \\
0.66 \\
0.85 \\
0.76\end{array}$ & $\begin{array}{l}277 \\
288 \\
288 \\
290 \\
288\end{array}$ & $\begin{array}{l}0.13 \\
0.17 \\
0.33 \\
0.43 \\
0.44\end{array}$ & $\begin{array}{l}0.71 \\
1.69 \\
1.77 \\
2.10 \\
1.80\end{array}$ & $\begin{array}{l}3.5 \\
4.3 \\
8.7 \\
8.8 \\
8.8\end{array}$ & $\begin{array}{l}3.3 \\
7.7 \\
7.9 \\
7.6 \\
7.5\end{array}$ \\
\hline
\end{tabular}

* Dog Fr. (8.2 Kg.). Aminonucleoside-induced lesion (109 days after induction). A simulated ECF solution was infused at the rate of $8.8 \mathrm{ml}$. per minute. Expanded volume was maintained by concurrent infusion of synthetic urine solutions.

majority of experiments, $\mathrm{C}_{\mathrm{H}_{2} \mathrm{O}} / \mathrm{GFR}$ increased in a roughly parallel manner bilaterally. However, values for $\mathrm{C}_{\mathrm{H}_{2} \mathrm{O}} / \mathrm{GFR}$ generally were greater for the experimental kidneys.

\section{DISCUSSION}

The present studies were designed to investigate the concentrating and diluting capacities of the diseased kidney. Within recent years several groups have suggested that isosthenuria in chronic bilateral renal disease may develop despite the persisting integrity of the concentrating and diluting mechanisms in the surviving nephrons.
This represents a departure from the conventional explanation which holds that the disease processes produce intrinsic abnormalities of the sites of concentration and dilution in the nephron. The experimental model in the present studies may help to distinguish between these two possibilities. Each animal possessed one normal and one diseased kidney. The presence of the normal kidney dictates that the combined (bilateral) nephron population must always exceed 50 per cent of the original number. Because of this, plasma urea levels have remained near-normal, and any compensatory increase in GFR (per remaining neph-

TABLE VI

Diluting capacity of the diseased and intact kidneys following sub-maximal water-load

\begin{tabular}{|c|c|c|c|c|c|c|c|c|c|c|c|}
\hline \multirow{2}{*}{$\begin{array}{l}\text { Clearance } \\
\text { period }\end{array}$} & \multicolumn{2}{|c|}{ GFR } & \multicolumn{2}{|c|}{ V } & \multicolumn{2}{|c|}{ Cosm } & \multirow[b]{2}{*}{ Posm } & \multicolumn{2}{|c|}{$\mathrm{C}_{\mathrm{H} 2 \mathrm{O}}$} & \multicolumn{2}{|c|}{$\begin{array}{c}\mathrm{CH}_{\mathrm{H} O} / \mathrm{GFR} \\
\times 100\end{array}$} \\
\hline & Exp. & Cont. & Exp. & Cont. & Exp. & Cont. & & Exp. & Cont. & Exp. & Cont. \\
\hline A. Dog Sl. & \multicolumn{2}{|c|}{$\begin{array}{c}\text { ml./min. } \\
(14.2 \mathrm{Kg} .)\end{array}$} & $\begin{array}{l}m b \\
\text { Reversible }\end{array}$ & $\begin{array}{c}\text { mb./min. } \\
\text { sible lesion }\end{array}$ & \multicolumn{2}{|c|}{$\begin{array}{l}\text { ml./min. } \\
\text { after induction) }\end{array}$} & mOsm./L. & \multicolumn{2}{|c|}{ ml./min. } & & \\
\hline $\begin{array}{r}1 \\
2 \\
3\end{array}$ & $\begin{array}{l}15.5 \\
13.8 \\
14.3\end{array}$ & $\begin{array}{l}37.0 \\
36.7 \\
35.5\end{array}$ & $\begin{array}{l}1.48 \\
1.60 \\
1.58\end{array}$ & $\begin{array}{l}2.11 \\
2.91 \\
3.35\end{array}$ & $\begin{array}{l}0.48 \\
0.40 \\
0.38\end{array}$ & $\begin{array}{l}1.38 \\
1.22 \\
1.11\end{array}$ & $\begin{array}{l}268 \\
273 \\
274\end{array}$ & $\begin{array}{l}1.00 \\
1.20 \\
1.20\end{array}$ & $\begin{array}{l}0.73 \\
1.69 \\
2.24\end{array}$ & $\begin{array}{l}6.5 \\
8.7 \\
8.4\end{array}$ & $\begin{array}{l}2.0 \\
4.6 \\
6.3\end{array}$ \\
\hline
\end{tabular}

B. Dog Da. (15.4 Kg.) Reversible lesion (13 days after induction)

$\begin{array}{llllllllllll}1 & 21.1 & 39.2 & 1.5 & 2.38 & 0.59 & 0.96 & 280 & 0.91 & 1.42 & 4.3 & 3.6 \\ 2 & 20.8 & 36.9 & 1.52 & 2.49 & 0.57 & 0.89 & 281 & 0.95 & 1.60 & 4.6 & 4.3 \\ 3 & 18.5 & 38.1 & 1.27 & 2.58 & 0.49 & 0.93 & 284 & 0.78 & 1.65 & 4.2 & 4.3\end{array}$

C. Dog Fr. (8.0 Kg.) Aminonucleoside-induced lesion (210 days after induction)

$\begin{array}{rrrrrrrrrrrr}1 & 6.5 & 44.7 & 0.10 & 1.25 & 0.16 & 0.77 & 265 & -0.06 & 0.48 & -0.9 & 1.1 \\ 2 & \mathbf{5 . 5} & 38.0 & 0.24 & 2.25 & 0.14 & 0.78 & 266 & 0.10 & 1.47 & 1.8 & 3.9 \\ 3 & 6.8 & 36.2 & 0.38 & 2.37 & 0.15 & 0.61 & 266 & 0.23 & 1.76 & 3.4 & 4.9 \\ 4 & 6.7 & 38.8 & 0.45 & 2.75 & 0.14 & 0.68 & 267 & 0.31 & 2.07 & 4.7 & 5.3\end{array}$

D. Dog Go. (17.4 Kg.) Pyelonephritis (25 days after induction)

\begin{tabular}{|c|c|c|c|c|c|c|c|c|c|c|}
\hline $\begin{array}{l}1 \\
2 \\
3\end{array}$ & $\begin{array}{l}37.2 \\
33.7 \\
34.1\end{array}$ & $\begin{array}{l}43.4 \\
40.6 \\
39.4\end{array}$ & $\begin{array}{l}0.73 \\
1.68 \\
2.13\end{array}$ & $\begin{array}{l}0.46 \\
1.42 \\
2.12\end{array}$ & $\begin{array}{l}0.66 \\
0.65 \\
0.52\end{array}$ & $\begin{array}{l}0.67 \\
0.68 \\
0.57\end{array}$ & $\begin{array}{l}265 \\
267 \\
270\end{array}$ & $\begin{array}{l}0.07 \\
1.03 \\
1.61\end{array}$ & $\begin{array}{r}-0.21 \\
0.74 \\
1.55\end{array}$ & $\begin{array}{rr}0.2 & -0.5 \\
3.1 & 1.8 \\
4.7 & 3.9\end{array}$ \\
\hline
\end{tabular}


ron) imposed by a marked decrease in bilateral nephron population would be minimized. If the conventional theory is substantially correct, the destruction of the sites of concentration and dilution should result in impaired concentrating and diluting ability in the diseased kidney regardless of the presence of an intact kidney, or of the status of body fluids. Conversely, if the isosthenuria results from a continuing osmotic diuresis (due either to high filtered loads of urea, or to an increased GFR/functioning nephron), the diseased kidney in the present experimental model might retain essentially normal concentrating and diluting characteristics.

In all animals studied, regardless of the severity of the renal lesion in the experimental kidney, values for the concentrating and diluting capacities (when expressed as ml. of $\mathrm{T}^{\mathbf{c}}{ }_{\mathrm{H}_{2} \mathrm{O}}$ or $\mathrm{C}_{\mathrm{H}_{2} \mathrm{O}}$ per $100 \mathrm{ml}$. of glomerular filtrate) have been within the normal range. These data serve to document the essential integrity of the concentrating and diluting processes in the persisting nephrons of the diseased kidneys. ${ }^{3}$ The same data suggest that the permanent isosthenuria of chronic Bright's disease may in most instances be explicable on the basis of functional rather than anatomic changes.

One functional change which occurs in the course of chronic progressing bilateral renal disease would appear to be of fundamental importance in the genesis of the restricted range of urine osmolalities. This consists of the fact that an ever-decreasing number of nephrons continue to excrete an essentially constant amount of solute. In order to accomplish this, each nephron must excrete an increasing fraction of its glomerular filtrate. The concentrating and diluting mechanisms of individual nephrons are thus brought to bear on an ever-increasing volume of tubular urine. Because of the rate limitations of these mechanisms, the degree to which the final

\footnotetext{
${ }^{3}$ Recent studies by Baldwin, Berman, Heinemann and Smith (10) on patients with bilateral renal disease are in general agreement with this conclusion. In the majority of subjects, values for $\mathrm{T}^{\mathrm{e}} \mathrm{H}_{2 \mathrm{O}} / \mathrm{GFR}$ were within the normal range. In those in whom values were below normal, it is not yet apparent whether this may be attributed to an absolute decrease in $\mathrm{T}^{\mathrm{c}}{ }_{\mathrm{H}_{2} \mathrm{O}}$ or to an increased GFR per nephron.
}

urine tonicity may be modified must decrease asymptotically towards isosmolality.

The concentrating mechanism would appear to be impaired before the diluting mechanism for several reasons. First, the absolute change from isosmolality (e.g., $300 \mathrm{mOsm}$. per L.) is considerably greater for a maximally concentrated urine (circa 1,200 mOsm. per L.) than for a maximally dilute urine (circa $50 \mathrm{mOsm}$. per L.). A 50 per cent reduction in range on either side of isosmolality, due to a twofold increase in tubular flow past the active sites, would seem to represent a much greater defect in concentration than dilution. Second, the amount of water abstracted per unit of glomerular filtrate in the concentrating process is approximately half the amount of freewater engendered in the diluting process (11). That a third factor may contribute to the loss of the ability to concentrate the urine before the ability to dilute the urine is suggested by certain observations in the present study. Thus, the data, while demonstrating the relative integrity of the concentrating and diluting mechanisms of the diseased organs, have also revealed certain differences between the diseased and intact kidneys of individual animals. These differences are characterized by slightly lower values for $\mathrm{T}^{\mathrm{c}} \mathrm{H}_{2} \mathrm{O} / \mathrm{GFR}$ for the experimental kidney, and slightly higher values for $\mathrm{C}_{\mathrm{H}_{2} \mathrm{O}} / \mathrm{GFR}$ for the experimental kidney. The urine from the diseased kidney, therefore, always has a greater amount of free-water (either relative or absolute) per unit of filtrate than that of the normal organ. The existence of a similar phenomenon in both kidneys of the patient with bilateral renal disease would contribute further to the masking of the concentrating mechanism before that of the diluting mechanism. Studies are currently in progress to extend these observations.

In Figure 1, a theoretical formulation is presented of the influence of progressive renal disease on the range of urine osmolalities if the concentrating and diluting capacities of all functioning nephrons remain normal. It is assumed that at each level of glomerular filtration rate 600 mOsm. of solute is excreted per 24 hours. Each nephron is assumed to be capable of removing 5 $\mathrm{ml}$. of water per $100 \mathrm{ml}$. of glomerular filtrate in the concentrating process (i.e., $\mathrm{T}^{\mathrm{c}} \mathrm{H}_{2 \mathrm{O}} / \mathrm{GFR} \times 100$ $=5$ ), and of engendering $10 \mathrm{ml}$. of free-water per 


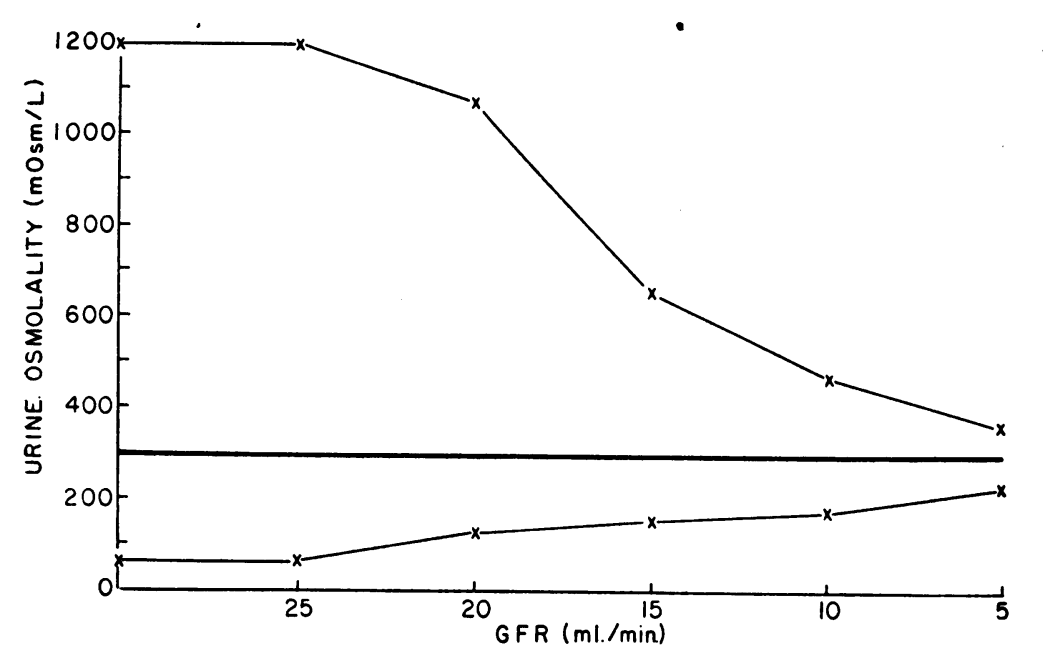

Fig. 1. Theoretical Curves Showing Maximum and Minimum Osmolalities in Progressive Renal Insufficiency if Concentrating and Diluting Capacities of EaCh FunCtioning NEPHRON REMain NORMAL

At each level of glomerular filtration rate, solute excretion is assumed to equal $600 \mathrm{mOsm}$. per 24 hours.

$100 \mathrm{ml}$. of filtrate in the diluting process (i.e., $\left.\mathrm{C}_{\mathrm{H}_{2} \mathrm{O}} / \mathrm{GFR} \times 100=10\right)$. Below a GFR of 20 ml. per minute progressive inability to concentrate the final urine is noted. Ability to dilute effectively persists longer but eventually diminishes markedly also.

\section{SUMMARY}

The mechanisms responsible for the impaired ability to concentrate and dilute the final urine in chronic progressive renal disease have never been adequately explained. The conventional theory holds that the disease process results in anatomic destruction of the concentrating and diluting sites in the nephron. An alternative concept holds that the concentrating and diluting mechanisms of the persisting nephrons remain intact and attributes the ultimate development of permanent isosthenuria to an increasing volume of urine flowing past the sites of these operations. In the present studies, the integrity of the concentrating and diluting mechanisms of the diseased kidney has been investigated in an attempt to distinguish between these two theories. One of three varieties of experimental renal disease has been induced in a single kidney of dogs in which the opposite kidney has been maintained intact as a control. The normal kidney served to prevent the evolution of body fluid abnormalities seen in bilateral renal disease. If the conventional theory is correct, the destruction of the sites of concentration and dilution in the diseased kidney should result in refractory isosthenuria regardless of the status of body fluids or of the presence of a contralateral intact organ.

In all the animals studied, regardless of the severity of the renal disease or the degree of anatomic disorganization, values for the concentrating and diluting capacities (expressed as $\mathrm{ml}$. of $\mathrm{T}^{\mathrm{c}} \mathrm{H}_{2} \mathrm{O}$ or $\mathrm{C}_{\mathrm{H}_{2} \mathrm{O}}$ per $100 \mathrm{ml}$. of glomerular filtrate) of the experimental kidneys were within the normal range. These data serve to document the essential integrity of the concentrating and diluting processes in the persisting nephrons of the diseased kidney, and strongly imply that the pathologic processes do not destroy specific functional sites in the tubule. A theoretical explanation has been offered which allows for the decreasing range of urine osmolalities in bilateral renal disease despite intact concentrating and diluting processes.

\section{ACKNOWLEDGMENTS}

We wish to thank Mr. Frank Dietz, Miss Claire Klein and $\mathrm{Mr}$. Leon Braitberg for invaluable technical assistance. 


\section{REFERENCES}

1. Berliner, R. W., Levinsky, N. G., Davidson, D. G., and Eden, M. Dilution and concentration of the urine and the action of antidiuretic hormone. Amer. J. Med. 1958, 24, 730.

2. Hayman, J. M., Jr., Shumway, N. P., Dumke, P., and Miller, M. Experimental hyposthenuria. J. clin. Invest. 1939, 18, 195.

3. Platt, R. Structural and functional adaptation in renal failure. Brit. med. J. 1952, 1, 1313, 1372.

4. Welt, L. G. The influence of disease on the renal excretion of water. Yale J. Biol. Med. 1956, 29, 299.

5. Strauss, M. B. Body Water in Man. Boston, Little, Brown \& Co., 1957.

6. Bricker, N. S., Lubowitz, H., Dewey, R. R., Stokes, J., and Goldman, D. Y. The functional capacity of persisting nephrons in experimentally induced chronic Bright's disease (abstract). J. Lab. clin. Med. 1957, 50, 796.
7. Bricker, N. S., Stokes, J. M., Lubowitz, H., Dewey, R. R., Bernard, H. R., and Hartroft, P. M. Experimentally induced permanent unilateral renal disease in dogs. J. Lab. clin. Med. 1958, 52, 571.

8. Bricker, N. S., Dewey, R. R., and Lubowitz, H. Studies in experimental pyelonephritis: Simultaneous and serial investigation of a pyelonephritic and intact kidney in the same animal. Clin. Res. 1958, 6, 292.

9. Bricker, N. S., Straffon, R. A., Mahoney, E. P., and Merrill, J. P. The functional capacity of the kidney denervated by autotransplantation in the dog. J. clin. Invest. 1958, 37, 185.

10. Baldwin, D. S., Berman, H. J., Heinemann, H. O., and Smith, H. W. The elaboration of concentrated urine in renal disease. J. clin. Invest. 1955, 34,800 .

11. Smith, H. W. Renal secretion of sodium and water. Fed. Proc. 1952, 11, 701. 